\title{
WYTRZYMAŁOŚĆ NA ŚCINANIE MIESZANINY POPIOLOWO-ŻUŻLOWEJ STABILIZOWANEJ SPOIWAMI HYDRAULICZNYMI
}

\begin{abstract}
Przedmiotem pracy jest mieszanina popiołowo-żużlowa pochodząca ze składowiska Elektrociepłowni Kraków (EDF Polska S.A.). Celem badań było określenie wytrzymałości na ścinanie przedmiotowej mieszaniny w aparacie bezpośredniego ścinania, w skrzynce o wymiarach w przekroju 0,1 x 0,1 i 0,12 x $0,12 \mathrm{~m}$, z ramkami pośrednimi tworzącymi strefę ścinania o grubości $10 \mathrm{~mm}$. Próbki formowano przy wilgotności optymalnej i wskaźniku zagęszczenia Is $=0,97$, a następnie ścinano: bezpośrednio po uformowaniu, po 7-dniowej pielęgnacji próbek stabilizowanych dodatkiem $2 \%$ (wagowo) spoiw hydraulicznych (dwa rodzaje) oraz po 7-dobowej pielęgnacji próbek stabilizowanych jak wyżej i następnie nasączanych wodą przez 3 doby. Uzyskane wartości parametrów charakteryzujących wytrzymałości na ścinanie, to jest kąta tarcia wewnętrznego i spójności, były stosunkowo duże, co świadczy o dużej wytrzymałości na ścinanie badanego materiału. Nawodnienie nie wpłynęło na wartość kąta tarcia wewnętrznego, natomiast wpłynęło na zmniejszenie spójności. Wartości tych parametrów w przypadku mieszanki stabilizowanej były wyraźnie zależne od rodzaju spoiwa.
\end{abstract}

Słowa kluczowe: odpady energetyczne, charakterystyka geotechniczna, parametry wytrzymałościowe

\section{Wprowadzenie}

W budownictwie i inżynierii lądowej wciąż aktualne jest poszukiwanie efektywnego sposobu wykorzystania surowców mineralnych z różnych źródeł, co wynika zarówno ze względów ekonomicznych, jak i z wymogów ochrony środowiska przyrodniczego. Taki kierunek działań obejmuje, oprócz wykorzy-

${ }^{1}$ Autor do korespondencji/corresponding author: Eugeniusz Zawisza, Uniwersytet Rolniczy im. H. Kołłątaja w Krakowie, Wydział Inżynierii Środowiska i Geodezji, Katedra Inżynierii Wodnej i Geotechniki, al. Mickiewicza 24/28, 30-059 Kraków, tel. 12 6339098, e-mail: kiwig@ur.edu.pl

2 Andrzej Gruchot, Uniwersytet Rolniczy im. H. Kołłątaja w Krakowie, Wydział Inżynierii Środowiska i Geodezji, Katedra Inżynierii Wodnej i Geotechniki, al. Mickiewicza 24/28, 30-059 Kraków, tel. 12 6624161, e-mail: rmgrucho@cyf-kr.edu.pl 
stania rezerw ziemnych ze złożami gruntów naturalnych, również możliwość stosowania ubocznych produktów działalności przemysłowej, które mogą stanowić ważny potencjał surowcowy. Dotyczy to odpadów przemysłu głównie hutniczego, węglowego i energetycznego $[12,13]$. Materiały te, w przypadku ich niewykorzystania zalegają w ogromnych ilościach na składowiskach, co powoduje konieczność przeznaczania na nie dużych terenów i utrudnia zagospodarowanie przestrzenne. Ponadto odpady przemysłowe deponowane na składowiskach wywierają niekorzystny wpływ na środowisko przyrodnicze, powodując zanieczyszczenie wód powierzchniowych i gruntowych oraz gleb i powietrza atmosferycznego [1, 3, 9]. Od wielu lat poszukuje się nowych sposobów gospodarczego wykorzystania materiałów odpadowych by zmniejszyć koszty składowania i ograniczyć niekorzystny wpływ na środowisko przyrodnicze. Największe możliwości wykorzystania odpadów przemysłowych stwarza szeroko pojęte budownictwo ogólne (produkcja cementu, betonów), górnictwo (podsadzki hydrauliczne) oraz budownictwo komunikacyjne i hydrotechniczne (nasypy drogowe, obwałowania, niwelacja i rekultywacja terenów) [2, 5]. Wykorzystanie odpadów przemysłowych do wyżej wymienionych celów związane jest z koniecznością wykonania badań ich właściwości geotechnicznych, których zakres i metodyka jest zależna głównie od źródła pochodzenia materiału, jego rodzaju, składu granulometrycznego i chemicznego. W niniejszej pracy przedstawiono wyniki badań właściwości geotechnicznych, a w szczególności wytrzymałości na ścinanie, wybranych odpadów poenergetycznych - mieszaniny popiołowożużlowej.

\section{Cel i metody badań}

Celem badań było określenie wartości parametrów charakteryzujących wytrzymałość na ścinanie mieszaniny popiołowo-żużlowej bez oraz z dodatkiem spoiwa Solitex lub Terramix F22,5. Materiał do badań pochodził z wieloletniego składowiska Elektrociepłowni Kraków (EDF Polska S.A.). Podstawowe parametry geotechniczne mieszaniny oznaczono metodami standardowymi $[4,10]$ : skład uziarnienia oznaczono metodą łączoną - sitową dla ziaren większych od $0,063 \mathrm{~mm}$ i areometryczną dla cząstek mniejszych. Gęstość właściwą szkieletu oznaczono metodą kolby miarowej w wodzie destylowanej. Wilgotność optymalną i maksymalną gęstość objętościową szkieletu oznaczono w aparacie Proctora w cylindrze o objętości $1 \mathrm{dm}^{3}$ przy energii zagęszczenia $0,59 \mathrm{~J} \cdot \mathrm{cm}^{-3}$. Wartości tych parametrów podano również dla mieszaniny z dodatkiem 3\% spoiwa Solitex lub Terramix F22,5 [11].

Wartości parametrów charakteryzujących wytrzymałość na ścinanie, to jest kąta tarcia wewnętrznego i spójności, oznaczono w aparacie bezpośredniego ścinania w skrzynce o wymiarach w przekroju $0,1 \times 0,1$ i $0,12 \times 0,12 \mathrm{~m}$, z ramkami pośrednimi tworzącymi strefę ścinania o grubości $10 \mathrm{~mm}$. Stosowanie ramek pośrednich umożliwia ścinanie strefowe, ograniczające wpływ zagęszcze- 
nia i klinowania się ziaren na wartość spójności (tzw. spójność pozorna). Próbki formowano bezpośrednio w skrzynce aparatu przy wilgotności optymalnej przez zagęszczanie materiału do uzyskania wskaźnika zagęszczenia $I_{S}=0,97$. Po uformowaniu próbki konsolidowano przy obciążeniu pionowym równym 50, 100, 200, 300 i $400 \mathrm{kPa}$ przez 30 minut i ścinano przy prędkości $0,25 \mathrm{~mm} \cdot \mathrm{min}^{-1}$ :

- bezpośrednio po uformowaniu próbki,

- po 3 dobach od nawodnienia próbek,

- po 7 dobach pielęgnacji próbek (w temperaturze pokojowej z zabezpieczeniem przed wysychaniem) stabilizowanych dodatkiem 2\% (wagowo) spoiwa Solitex lub Terramix F22,5,

- po 7 dobach pielęgnacji jak wyżej próbek stabilizowanych dodatkiem $2 \%$ spoiwa Solitex lub Terramix F22,5 i następnie nawadnianych przez 3 doby.

We wcześniejszych badaniach [11] określono również mrozoodporność tego materiału stabilizowanego dodatkiem 3, 6 i 8\% spoiwa Solitex lub Terramix F22,5, których wyniki uwzględniono w niniejszej pracy.

\section{Wyniki badań}

Skład uziarnienia pozwolił sklasyfikować badaną mieszaninę pod względem geotechnicznym jako kilkufrakcyjny piasek drobny pylasty (tab. 1.). Gęstość właściwa szkieletu wynosiła $2,42 \mathrm{t} \cdot \mathrm{m}^{-3}$. Wilgotność naturalna wynosiła od około 17 do $25 \%$. Parametry zagęszczalności wynosiły - wilgotność optymalna ponad $36 \%$, a maksymalna gęstość objętościowa szkieletu około $1,15 \mathrm{t} \cdot \mathrm{m}^{-3}$. Wartość tych parametrów mieszaniny z dodatkiem 3\% spoiwa Solitex lub Terramix F22,5 nie zmieniły się w sposób istotny w stosunku do wartości dla samej mieszaniny (rys. 1.).

Tabela 1. Podstawowe właściwości fizyczne mieszaniny popiołowo-żużlowej [11]

Table 1. Basic physical properties of the ash-slag mixture [11]

\begin{tabular}{|l|c|}
\hline Parametr & Wartość \\
\hline Zawartość frakcji [\%]: & 7,0 \\
- żwirowa 63-2 mm & 58,9 \\
- piaskowa 2-0,063 mm & 32,5 \\
- pyłowa 0,063-0,002 mm & 1,7 \\
- iłowa <0,002 mm & siFSa \\
Nazwa wg: PN-EN ISO 14688-2:2006 & 10,6 \\
Wskaźnik różnoziarnistości [-] & 2,42 \\
Gęstość właściwa szkieletu [t.m $\left.{ }^{-3}\right]$ & \\
\hline
\end{tabular}




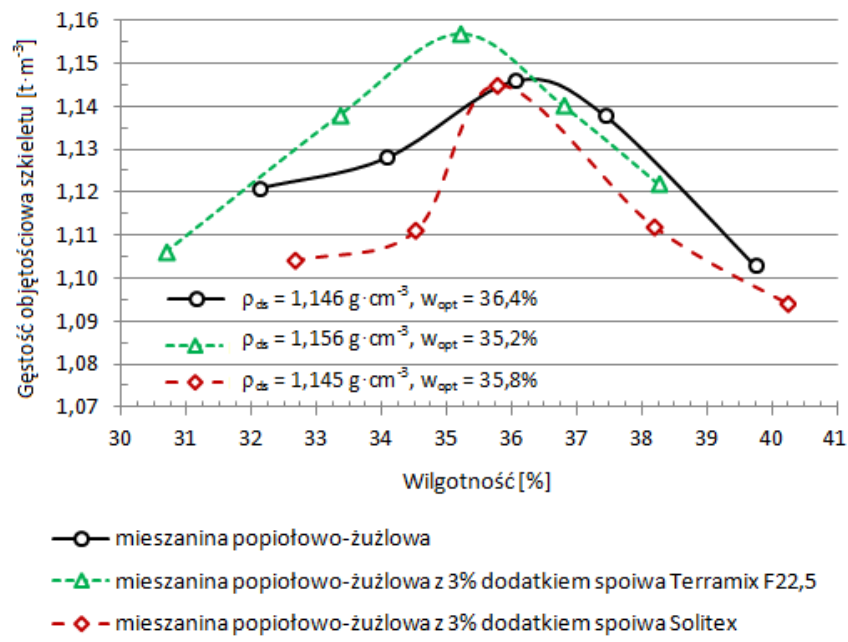

Rys. 1. Wykresy zależności gęstości objętościowej szkieletu od wilgotności [11]

Fig. 1. Dry density versus moisture content [11]

Wyniki badań wytrzymałości na ścinanie mieszaniny popiołowo-żużlowej zestawiono $\mathrm{w}$ tabeli 2. Uzyskane wartości kąta tarcia wewnętrznego (średnio $34^{\circ}$ ) i spójności (średnio 44,6 $\mathrm{kPa}$ ) są stosunkowo duże i świadczą o dużej wytrzymałości na ścinanie badanego materiału. Wartości tych parametrów po 3 dobach nawadniania próbek wynosiły średnio: kąt tarcia wewnętrznego $34,2^{\circ}$, a spójność - $9 \mathrm{kPa}$. Wskazują one, że nawodnienie nie wpłynęło na wartość kąta wewnętrznego, natomiast znacznie zmniejszyło spójność. Wyniki ścinania mieszaniny z dodatkiem $2 \%$ spoiwa Solitex, po 7 dobach pielęgnacji próbek w temperaturze pokojowej z zabezpieczeniem przed wysychaniem, wykazały wartość parametrów wytrzymałościowych zbliżone do wartości dla tego materiału bez dodatku spoiwa: kąt tarcia wewnętrznego wynosił $33,6^{\circ}$, a spójność 45,3 $\mathrm{kPa}$. Po 7 dobach pielęgnacji i 3 dobach nawadniania wartość kąta tarcia wewnętrznego nie zmieniła się w sposób istotny (średnio $35,3^{\circ}$ ), natomiast spójność zmniejszyła się do około $23 \mathrm{kPa}$.

Wyniki ścinania tego samego materiału, lecz z dodatkiem $2 \%$ spoiwa Terramix F22,5 po 7 dobach pielęgnacji próbek $\mathrm{w}$ temperaturze pokojowej z zabezpieczeniem przed wysychaniem wykazały następujące wartości parametrów wytrzymałościowych: kąt tarcia wewnętrznego - 39,40ª a spójność - 43,2 kPa. Wartości te wskazują na dość wyraźne zwiększenie kąta tarcia wewnętrznego, natomiast spójność nie uległa istotnym zmianom w stosunku do materiału bez dodatku spoiwa. Wyniki ścinania tego samego materiału po 7 dobach pielęgnacji próbek i 3 dobach nawadniania wykazały następujące wartości parametrów wytrzymałościowych: kąt tarcia wewnętrznego - 39,3, a spójność - 38,7 kPa. Wskazują one, że nawodnienie nie wpłynęło w sposób istotny na wytrzymałość na ścinanie badanego materiału, jedynie wartość spójności zmniejszyła się o 4,5 kPa. 
Tabela 2. Zestawienie wyników badania wytrzymałości na ścinanie mieszaniny popiołowożużlowej

Table 2. Results of shear strength tests of the ash-slag mixture

\begin{tabular}{|c|c|c|c|c|c|c|}
\hline \multirow[b]{3}{*}{ Materiał } & \multicolumn{6}{|c|}{ Wartości parametrów wytrzymałościowych próbek: } \\
\hline & \multicolumn{3}{|c|}{ nienawodnionych } & \multicolumn{3}{|c|}{ nawodnionych } \\
\hline & $\begin{array}{c}\mathrm{Nr} \\
\text { prób- } \\
\text { ki }\end{array}$ & $\begin{array}{l}\text { Kąt tarcia } \\
\text { wewnętrz- } \\
\text { nego, } \phi\left[^{\circ}\right] \\
\end{array}$ & $\begin{array}{l}\text { Spójność } \\
\text { c [kPa] }\end{array}$ & $\begin{array}{c}\mathrm{Nr} \\
\text { prób- } \\
\text { ki }\end{array}$ & $\begin{array}{l}\text { Kąt tarcia } \\
\text { wewnętrz- } \\
\text { nego, } \phi\left[^{\circ}\right]\end{array}$ & $\begin{array}{l}\text { Spójność } \\
\text { c [kPa] }\end{array}$ \\
\hline \multirow{5}{*}{$\begin{array}{l}\text { Mieszanina po- } \\
\text { piołowo-żużlowa } \\
\text { bez dodatku spo- } \\
\text { iwa }\end{array}$} & \multicolumn{3}{|c|}{$\begin{array}{l}\text { ścinanie bezpośrednio po uformo- } \\
\text { waniu próbek }\end{array}$} & \multicolumn{3}{|c|}{$\begin{array}{c}\text { ścinanie po } 3 \text { dobach nawadniania } \\
\text { próbek }\end{array}$} \\
\hline & 1 & 33,2 & 48,2 & $1 \mathrm{w}$ & 36,4 & 5,8 \\
\hline & 2 & 34,2 & 43,1 & $2 \mathrm{w}$ & 33,7 & 12,1 \\
\hline & 3 & 34,7 & 42,5 & & & \\
\hline & $\begin{array}{l}\text { śred- } \\
\text { nia }\end{array}$ & 34,0 & 44,6 & $\begin{array}{c}\text { śred- } \\
\text { nia }\end{array}$ & 34,2 & 9,0 \\
\hline \multirow{4}{*}{$\begin{array}{l}\text { Mieszanina po- } \\
\text { piołowo-żużlowa } \\
\text { z } 2 \% \text { dodatkiem } \\
\text { spoiwa Terramix } \\
\text { F22,5 }\end{array}$} & \multicolumn{3}{|c|}{$\begin{array}{c}\text { ścinanie po } 7 \text { dobach pielęgnacji } \\
\text { próbek* }\end{array}$} & \multicolumn{3}{|c|}{$\begin{array}{l}\text { ścinanie po } 7 \text { dobach pielęgnacji* } \\
\text { i } 3 \text { dobach nawodnienia próbek }\end{array}$} \\
\hline & F1 & 39,7 & 30,9 & F3 & 40,0 & 34,6 \\
\hline & $\mathrm{F} 2$ & 39,0 & 55,4 & F4 & 38,5 & 42,8 \\
\hline & $\begin{array}{c}\text { śred- } \\
\text { nia }\end{array}$ & 39,4 & 43,2 & $\begin{array}{c}\text { śred- } \\
\text { nia }\end{array}$ & 39,3 & 38,7 \\
\hline \multirow{4}{*}{$\begin{array}{l}\text { Mieszanina po- } \\
\text { piołowo-żużlowa } \\
\text { z } 2 \% \text { dodatkiem } \\
\text { spoiwa Solitex }\end{array}$} & \multicolumn{3}{|c|}{$\begin{array}{l}\text { ścinanie po } 7 \text { dobach pielęgnacji } \\
\text { próbek* }\end{array}$} & \multicolumn{3}{|c|}{$\begin{array}{l}\text { ścinanie po } 7 \text { dobach pielęgnacji* } \\
\text { i } 3 \text { dobach nawodnienia próbek }\end{array}$} \\
\hline & S1 & 33,6 & 43,9 & S3 & 35,8 & 23,3 \\
\hline & $\mathrm{S} 2$ & 33,6 & 46,6 & $\mathrm{~S} 4$ & 34,8 & 22,3 \\
\hline & $\begin{array}{l}\text { śred- } \\
\text { nia }\end{array}$ & 33,6 & 45,3 & $\begin{array}{c}\text { śred } \\
\text { nia }\end{array}$ & 35,3 & 22,8 \\
\hline
\end{tabular}

* - w temperaturze pokojowej z zabezpieczeniem przed wysychaniem

\section{Dyskusja wyników}

Wytrzymałość na ścinanie badanej mieszaniny popiołowo-żużlowej wykazała zależność od warunków wodnych (rys. 2.). Przy wilgotności optymalnej i dużym zagęszczeniu $\left(I_{S}=0,97\right)$ wytrzymałość na ścinanie mieszaniny była stosunkowo duża porównywalna do wytrzymałości zagęszczonych gruntów naturalnych niespoistych, na przykład piasków średnich [10]. Po nawodnieniu wartość kąta tarcia wewnętrznego mieszaniny nie uległa zmianie, natomiast wartość spójności zmniejszyła się prawie 5-krotnie, co świadczy o wrażliwości materiału na czynnik wodny.

Wytrzymałość na ścinanie mieszaniny popiołowo-żużlowej stabilizowanej spoiwami hydraulicznymi była zależna od rodzaju spoiwa i warunków wodnych. W przypadku próbek o wilgotności optymalnej stabilizowanych spoiwem Terramix F22,5 po 7 dobach pielęgnacji kąt tarcia wewnętrznego zwiększył się o około $16 \%$, natomiast spójność praktycznie nie uległa zmianie w stosunku do wartości tego parametru mieszaniny niestabilizowanej, co świadczy o wzroście wytrzymałości na ścinanie. Po nawodnieniu wartość kąta tarcia wewnętrznego nie 
a)

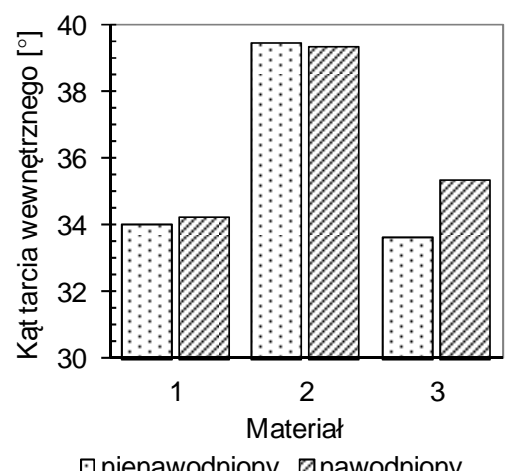

b)

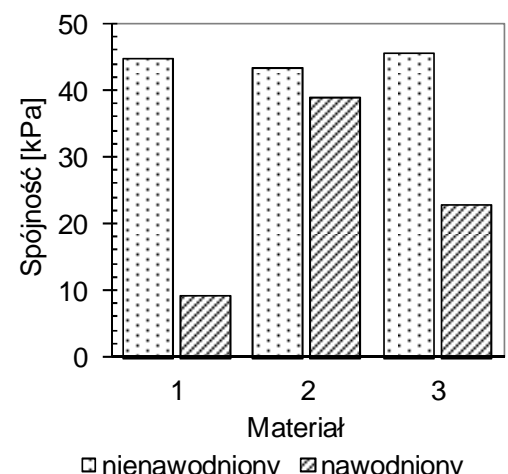

1 - mieszanina popiołowo-żużlowa, 2 - mieszanina popiołowo-żużlowa z dodatkiem $2 \%$ spoiwa Terramix F22,5, 3 - mieszanina popiołowo-żużlowa z dodatkiem 2\% spoiwa Solitex

Rys. 2. Wartości kąta tarcia wewnętrznego (a) i spójności (b) w zależności od warunków wodnych i rodzaju spoiwa

Fig. 2. Values of the angle of internal friction (a) and cohesion (b) in relation to water conditions and binder type

zmieniła się, natomiast spójność zmniejszyła się o 10\%, przy czym była ona ponad 4-krotnie większa od spójności mieszaniny niestabilizowanej. Świadczy to o korzystnym efekcie stabilizacji mieszaniny spoiwem Terramix F22,5. Mieszanina przy dodatku 6 i 8\% spoiwa Terramix F22,5 wykazała mrozoodporność [11], co potwierdza korzystny efekt stabilizacji tym spoiwem.

W przypadku próbek o wilgotności optymalnej stabilizowanych spoiwem Solitex, po 7 dobach pielęgnacji wartości zarówno kąta tarcia wewnętrznego, jak i spójności, pozostały na tym samym poziomie jak dla mieszaniny niestabilizowanej, a więc wytrzymałość na ścinanie mieszaniny nie uległa zmianie. Po nawodnieniu wartość kąta tarcia wewnętrznego praktycznie nie uległa zmianie, natomiast wartość spójności zmniejszyła się około 50\%, przy czym była ona ponad 2,5-krotnie większa od spójności mieszaniny niestabilizowanej. Przedstawione dane świadczą o braku korzystnego efektu stabilizacji mieszaniny spoiwem Solitex. Również przy większym dodatku tego spoiwa - 6 i $8 \%$ nie uzyskano korzystnego efektu stabilizacji, bowiem materiał nie wykazał mrozoodporności [11].

\section{Podsumowanie}

Przeprowadzone badania oraz analiza ich wyników wykazała, że mieszanina popiołowo-żużlowa ze składowiska Elektrociepłowni „Kraków” EDF odznacza się stosunkowo dużą wytrzymałością na ścinanie. Pozwala to prognozować dobrą stateczność skarp nasypów formowanych z tego materiału przy zachowa- 
niu odpowiedniej wilgotności (zbliżonej do optymalnej) i dużym zagęszczeniu $\left(I_{s} \geq 0,95\right)$. Ze względu jednak na wrażliwość na oddziaływanie wody może być stosowana na dolne warstwy nasypów drogowych poniżej głębokości przemarzania, w miejscach suchych lub izolowanych od wód gruntowych i powierzchniowych.

Stabilizacja mieszaniny popiołowo-żużlowej spoiwem Solitex nie przyniosła pozytywnych efektów. Materiał wykazywał, podobnie jak sama mieszanina, wrażliwość na oddziaływanie wody. Wyniki badań mrozoodporności tego samego materiału stabilizowanego spoiwem Solitex, przedstawione w pracy Zawiszy i in. [11], wykazały również nieskuteczność stabilizacji tym spoiwem czyli brak mrozoodporności.

Stabilizacja mieszaniny popiołowo-żużlowej spoiwem Terramix F22,5 przyniosła pozytywne efekty - nastąpiło zwiększenie wytrzymałości na ścinanie i odporności na oddziaływanie wody. Również badania mrozoodporności [11] wykazały jej odporność na oddziaływanie niskich temperatur, lecz dopiero przy dodatku przynajmniej $6 \%$ spoiwa. Wskazuje to, że mieszanina popiołowożużlowa z takim dodatkiem spoiwa Terramix F22,5 może być stosowana również na górne warstwy nasypów drogowych w strefie przemarzania przy zachowaniu wymogów określonych w odnośnych normatywach $[7,8]$.

\section{Literatura}

[1] Kucowski J., Laudyn D., Przekwas M., Energetyka a ochrona środowiska. WNT 1987.

[2] Kuzio B., Labryga B. Analiza stanu gospodarki odpadami z energetyki. Mat. Konf. „Energetyka a ochrona środowiska”. Ustroń-Jaszowiec 1996.

[3] Miczyński J., Kozak L., Zawisza E. Wpływ składowiska Przezchlebie na stan zanieczyszczenia powietrza atmosferycznego. Materiały z XI Konf. „Zapobieganie zanieczyszczeniu środowiska”. Zesz. Nauk. ATH w Bielsku-Białej - Inżynieria Włókiennicza i Ochrona Środowiska 14 (5). S. 144-148. Bielsko-Biała 2004.

[4] Myślińska E., Laboratoryjne badania gruntów. Wydawnictwo Naukowe PWN, Warszawa 1998.

[5] Pisarczyk S., Grunty nasypowe. Właściwości geotechniczne i metody ich badania. Oficyna Wydawnicza Politechniki Warszawskiej 2004.

[6] PN-EN ISO 1468 8-2:2006. Badania geotechniczne. Oznaczenie i klasyfikowanie gruntów. Część 2: Zasady klasyfikowania. Polski Komitet Normalizacyjny, Warszawa 2006.

[7] PN-S-02205:1998. Drogi samochodowe. Roboty ziemne. Wymagania i badania. Polski Komitet Normalizacyjny, Warszawa 1998.

[8] PN-S-06102:1997. Drogi samochodowe. Podbudowy z kruszyw stabilizowanych mechanicznie. Polski Komitet Normalizacyjny, Warszawa 1997.

[9] Rosik-Dulewska Cz., Podstawy gospodarowania odpadami. Wyd. Ekoinżynieria. Lublin 1999.

[10] Wiłun Z., Zarys geotechniki. Wydawnictwo Komunikacji i Łączności, Warszawa 2000. 
[11]Zawisza E., Biśtyga J., Kopczyński M. Wytrzymałość na ścinanie i mrozoodporność popioło-żużla stabilizowanego spoiwami hydraulicznymi. Acta Sci. Pol. Kraków 2017.

[12]Zawisza E., Geotechniczne i środowiskowe aspekty uszczelniania grubookruchowych odpadów powęglowych popiołami lotnymi. Zeszyty Naukowe AR im. H. Kołłątaja w Krakowie. Rozprawy Z. 280, Wydawnictwo AR w Krakowie 2001.

[13]Zawisza E., Odpady hutnicze jako antropogeniczne grunty budowlane. Metody badań i właściwości geotechniczne. Wydawnictwo UR, Kraków. Acta Sci. Pol. 2012.

\section{SHEAR STRENGTH OF THE ASH-SLAG MIXTURE STABILISED WITH HYDRAULIC BINDERS}

\section{S u m m a r y}

The ash-slag mixture coming from the landfill of the Combined Heat and Power Plant Kraków EDF is the subject of the work. The tests aimed at the determination of the shear strength of this mixture in a direct shear apparatus, in a box with dimensions of $0.1 \times 0.1$ or $0.12 \times 0.12 \mathrm{~m}$, with intermediate frames forming $10 \mathrm{~mm}$ thick shear zone. The samples were moulded at the optimum moisture content and the degree of compaction $\mathrm{I}_{\mathrm{S}}=0,97$, and then sheared: immediately after moulding, after 7-day curing of the samples stabilised with addition of $2 \%$ (by weight) of hydraulic binders (two types) and after 7-day curing of the samples stabilised as above and then soaked in water for three days. The obtained values of the parameters characterising the shear strength, i.e. the angle of internal friction and cohesion, were relatively high, indicating a high shear strength of the tested material. Moisturising did not affect the value of the angle of internal friction, but reduced cohesion. The values of these parameters for the stabilised mixture were clearly dependent on the type of binder.

Keywords: fuel ash, geotechnical characteristics, strength parameters

Przestano do redakcji: 01.06.2017 r.

Przyjęto do druku: 01.09.2017 r. 